\title{
PENERAPAN KONSEP LAND BANKING DI INDONESIA UNTUK PEMBANGUNAN PERUMAHAN MBR DI KAWASAN PERKOTAAN
}

\author{
Noegi Noegroho \\ Architecture Department, Faculty of Engineering, Binus University \\ Jl. K.H. Syahdan No. 9, Palmerah, Jakarta Barat 11480 \\ noeginoegroho@gmail.com
}

\begin{abstract}
In line with the increase of population, the need for housing continues to increase as well. This is a classic issue in urban areas when land prices continues to rise so that some recidences belongs only to high society The concept of Land Banking could be as one solution to acquire land which is feasible to be built for low income housing. This paper discusses about the concept of land banking and how it is applied in Indonesia.
\end{abstract}

Keywords: urban area, land price, land banking, low income housing

\begin{abstract}
ABSTRAK
Sejalan dengan bertambahnya jumlah penduduk, kebutuhan akan perumahan pun terus bertambah. Hal ini menjadi permasalahan yang klasik di kawasan perkotaan ketika harga tanah pun terus melonjak sehingga perumahan hanya menjadi milik masyarakat 'mampu'. Konsep Land Banking (Bank Tanah) disebut sebagai salah satu solusi untuk memperoleh tanah sekaligus untuk meredam gejolak tanah di perkotaan sehingga layak dibangun perumahan masyarakat berpenghasilan rendah (MBR). Tulisan ini membahas tentang konsep Land Banking dan bagaimana konsep ini diterapkan di Indonesia.
\end{abstract}

Kata kunci: kawasan perkotaan, harga tanah, bank tanah, perumahan masyarakat berpenghasilan rendah $(M B R)$ 


\section{PENDAHULUAN}

Kota-kota di Indonesia masih menghadapi masalah utama terkait penyediaan perumahan bagi warganya. Kebutuhan akan perumahan jauh lebih tinggi dari ketersediaan yang ada. Badan Pusat Statistik mencatat besarnya kebutuhan rumah pada tahun 2010 mencapai 13 juta unit (Kompas, 18 Des 2011). Jika dihitung setiap tahunnya dibutuhkan rumah sebanyak 700 ribu unit pertahun padahal kemampuan penyediaan rumah hanya bisa mencapai 200 ribu unit pertahun (Kompas, 28 Maret 2011). Ketua DPP Real Estate Indonesia menyebutkan bahwa kebutuhan rumah di Indonesia mencapai angka 2,6 juta pertahun, suatu jumlah yang sangat besar. Kebutuhan jumlah rumah sebanyak itu diakibatkan kebutuhan alami karena pertumbuhan penduduk, kondisi rumah tidak layak yang ada saat ini danbacklog perumahan yang terakumulasi dari dulu hingga sekarang. Rumah yang dibutuhkan tersebar di seluruh Indonesia, sebagian besar kebutuhan berada di kawasan perkotaanterutama adalah rumah bagi Masyarakat Menengah ke Bawah atau Masyarakat Berpenghasilan Rendah (MBR). Mengapa begitu sulit membangun perumahan di perkotaan khususnya perumahan bagi MBR? Salah satu fakor penghambat utama adalah masalah lahan. Lahan yang terbatas menyebabkan ketidak seimbangan supply dan demand sehingga menyebabkan harga tanah menjadi mahal. Harga tanah yang mahal tidak menjadi masalah jika produk yang dihasilkan adalah rumah bagi masyarakat mampu, tapi akan menjadi masalah jika produk yang dihasilkan adalah rumah murah bagi MBR.

Ditinjau dari segala fasilitas yang ada, tanah di perkotaan memang memiliki nilai strategis lebih tinggi dibandingkan dengan tanah di pedesaan. Kelengkapan fasilitas, infrastruktur dan kemudahan aksesibilitas membuat banyak masyarakat ingin tinggal di kawasan perkotaan. Akibatnya kebutuhan akan tanah di kawasan perkotaan meningkat pesat. Bahkan tidak jarang masyarakat rela berdesakan dalam area sempit demi tinggal di kawasan perkotaan. Ketidakseimbangan antara supply dan demand ini kemudian mengakibatkan harga tanah di kawasan perkotaan pun melonjak. Berdasarkan hasil tinjauan di lapangan pada bulan Juli 2012, harga tanah di kota Jakarta memang terus meningkat. Sebagai contoh, harga tanah di area Pantai Indah Kapuk mencapai Rp 9 - 10 jt/m², di area Puri Indah sudah mencapai Rp $7-8 \mathrm{jt} / \mathrm{m}^{2}$. Harga ini tentu akan semakin tinggi jika lokasinya mendekati pusat kota Jakarta.Bagaimana harga tanah di luar Jakarta? tanah di Bumi Serpong Damai sudah berada di kisaran Rp 4 - 5 jt/m² , di area Cibubur mencapai Rp 5- 6 jt $/ \mathrm{m}^{2}$ (Data yang diambil merupakan harga-harga tanah di dalam komplek perumahan yang sudah lengkap infrastrukturnya, harga diluar komplek bisa saja lebih murah tapi masih diperlukan pembangunan infrastruktur pendukung). Dengan harga tanah seperti ini tentu sulit untuk membangun perumahan yang terjangkau MBR di kawasan perkotaan, bahkan dengan membangun rumah susun (rusun) sekalipun. Idealnya harga tanah untuk dibangun rumah susun dibawahRp1 juta/ $\mathrm{m}^{2}$, tapi tidak semua tanah di Jakarta yang layak dibangun (rusun) berada pada harga ini.

Akibat tingginya harga tanah di kawasan perkotaan tentu mengakibatkan harga rumah pun menjadi tinggi, kondisi ini semakin menjauhkan akses MBR untuk memiliki rumah. Tidak jarang kemudian mereka membangun rumah seadanya yang menimbulkan masalah lain di perkotaan (permukiman kumuh, kriminalitas tinggi, perumahan rawan kebakaran dll.). Melihat kondisi ini, yang menjadi masalah utama dalam penyediaan perumahan MBR adalah ketersediaan lahan dengan harga yang terjangkau. Salah satu alternatif solusinya adalah dengan mekanisme Land Banking (bank Tanah). Prinsip Land Banking adalah penyediaan lahan dengan 'mencuri' waktu di mana pembangunan yang direncanakan masih jauh di depan. Dengan 'mencuri' waktu tersebut diharapkan tanah sebagai komponen basic cost pembangunan perumahan bisa diperoleh dengah minimum sehingga menjadi layak untuk dibangun perumahan MBR. Tulisan ini membahas konsep Land Banking sebagai solusi memperoleh lahan dan bagaimana penerapannya di Indonesia. 


\section{METODE}

Studi tentang konsep Land Banking dan penerapannya di Indonesia ini dibahas berdasarkan metode tinjauan pustaka yang diambil dari beberapa referensi terkait.

\section{HASIL DAN PEMBAHASAN}

\section{Konsep Land Banking dan Manfaatnya}

Konsep Land Banking sudah dicetuskan di negara Barat sejak tahun 1900an. Diawali di Amsterdam tahun 1890 sebagai sebuah cara untuk mendapatkan lahan dan kemudian mencadangkannya untuk keperluan lahan pembangunan. Cara-cara seperti ini kemudian diadopsi oleh negara lain di eropa hingga kemudian pada tahun 1970-an diadopsi di beberapa kota di Amerika dan di beberapa kota di Asia seperti Singapura, China dan Hongkong.

Ada beberapa pengertian tentang Land Banking. Menurut Ali Tranghada Land Banking adalah suatu proses pembelian tanah dan properti dengan harga sekarang untuk kemudian menyimpan dan dikembangkan untuk keperluan tertentu sehingga mempunyai nilai tambah. Evans (2004) mengatakan bahwa land banking as acquisition of land ahead of development either by construction companies or by central or local government or their agencies. Pada pengertian yang terakhir, disebutkan pihakpihak yang melaksanakan mekanisme Land Banking tersebut.Hal ini juga disebutkan oleh Annaningsih (2007) yang menjelaskan bahwa Konsep Land Banking adalah suatu proses pembelian tanah dan properti untuk keperluan di masa mendatang di mana setiap individu, kelompok atau perusahaan dapat membeli tanah dengan harga riil saat itu untuk selanjutnya mengembangkan tanah tersebut guna keperluan tertentu sehingga memiliki nilai tambah dan pada akhirnya nilai ekonomis tanah akan meningkat.

Namun ada juga yang memberi pengertian berbeda dengan di atas dalam hal siapa pihak yang melaksanakan mekanisme Land Banking. Alexander (2011) menjelaskan bahwa land banking is the process or policy by which local governments acquire surplus properties and convert them to productive use or hold them for long-term strategic public purposes. Selanjutnya, Wilson, J. menyebutkan Land Banking is a government financial institution mandated to spur countryside development, with its mission to promote grow and properity, especially in the countryside. It has taken the lead in extending financial assistance to various development players. Dalam penjelasan ini disebutkan bahwa mekanisme Land Banking diperuntukan untuk penyedian tanah guna keperluan publik dan kesejahteraan masyarakat. Oleh karena itu dibutuhkan campur tangan pemerintah. Lain lagi dengan Department of Housing and Urban Development yang memberikan penjelasan berbeda, bahwa pelaksana Land Banking adalah komunitas masyarakat dan bukan lembaga keuangan. Land Bankings are not financial institutions. They are public or community-owned entities created for a single purpose: to acquire, manage, maintain, and repurpose vacant, abandoned, and foreclosed properties -the worst abandoned houses, forgotten buildings, and empty lots.

Dari beberapa pengertian di atas, terdapat point penting bahwa Land Banking diperuntukan untuk memperoleh tanah yang kemudian digunakan untuk kepentingan mensejahterakan masyarakat khususnya kebutuhan rumah. Yang menjadi perbedaan adalah pihak mana yang sesungguhnya berhak untuk menyelenggarakan land banking. Namun Annaningsih (2007) menjelaskan bahwa karena tanah memiliki nilai ekonomi yang tinggi dan memiliki peranan penting bagi kehidupan masyarakat maka sudah seharusnya pihak pemerintahlah yang melaksanakannya. Hal ini berkaitan bahwa tanah yang diperoleh digunakan untuk kesejahteraan seluruh masyarakat terutama golongan MBR. 
Ditinjau dari fungsinya, Land Banking memiliki beberapa fungsi menurut Siregar (2004) dalam Annaningsih (2007) adalah sebagai berikut: (1) land keeper, sebagai penghimpun tanah yaitu inventarisasi dan pengembangan database tanah, administrasi dan penyediaan sistem informasi pertanahan.; (2) land warantee, sebagai pengamanan tanah yaitu menjamin penyediaan tanah untuk pembangunan, menjamin nilai tanah dan efisiensi pasar tanah yang berkeadilan, dan mengamankan peruntukkan tanah secara optimal; (3) land purchaser, sebagai pengendali tanah yaitu penguasaan tanah, penetapan harga tanah yang terkait dengan persepsi kesamaan nilai pajak bumi dan bangunan; (4) land valuer, sebagai penilai tanah yaitu melakukan penilaian tanah yang obyektif dalam menciptakan satu sistem nilai dalam penentuan nilai tanah yang berlaku untuk berbagai keperluan; (5) land distributor, sebagai penyalur tanah yaitu menjamin distribusi tanah yang wajar dan adil berdasarkan kesatuan nilai tanah, mengamankan perencanaan, penyediaan dan distribusi tanah; (6) land management, sebagai manajer tanah yaitu melakukan manajemen pertanahan yang merupakan bagian dan manajemen aset secara keseluruhan, melakukan analisis, penetapan strategi dan pengelolaan implementasi berkaitan dengan pertanahan.

Adapun manfaat penerapan konsep Land Banking menurut Limbong antara lain: (1) tersedianya lahan untuk pembangunan sehingga rencana pembangunan oleh pemerintah maupun swasta tidak terhambat; (2) ketersediaan tanah sepanjang waktu untuk pembangunan sehingga investor memperoleh kepastian; (3) efisiensi ditinjau dari penghematan dalam proses pembebasan lahan yang umumnya berlarut-larut. Sedangkan menurut Siregar, manfaat yang diperoleh adalah: (1) mampu mengendalikan keseimbangan antara kebutuhan tanah untuk pembangunan dan ketersediaan tanah; (2) mampu mengendalikan mekanisme pasar tanah yang menjamin efisiensi dan rasionalitas harga tanah; (3) mampu mengefisiensikan dan menjamin nilai tanah yang wajar dan adil; (4) mampu memadukan kebijakan, strategi, implementasi dan evaluasi yang berkaitan dengan tanah.

\section{Penerapan Konsep Land Banking di Indonesia dalam Penyediaan Lahan untuk Kawasan Perumahan}

Bagi Indonesia, penerapan konsep Land Banking dapat dilaksanakan. Ada beberapa objek tanah yang bisa dicadangkan sebagai objekland Banking ini. Menurut Limbong, beberapa tanah yang dapat dijadikan objek Land Banking antara lain: tanah bekas HGU, tanah terlantar, tanah fasus/fasos yang sudah diserahkan oleh developer, tanah-tanah aset BPPN, tanah aset departemen/lembaga pemerintah non departemen/pemda yang belum digunakan, tanah negara yang berasal dari Pencabutan Hak, tanah negara yang berasal dari pembebasan tanah dan tanah milik BUMN/BUMD. Memang belum ada data yang dapat memperlihatkan berapa besar potensi objek Land Banking tersebut. Namun didukung oleh sistem Hukum Agraria yang adadi Indonesia, sudah ada payung hukum yg dimungkinkan bagi Negara untuk menguasai tanah. Bahkan, penerapan konsep Land Banking ini semakin kuat dengan dikeluarkannya Undang-Undang no. 2 tahun 2012 tentang Pengadaan Tanah untuk Pembangunan bagi Kepentingan Umum yang menjadi payung hukum dalam pengadaan tanah untuk pembangunan baik bagi pemerintah maupun pihak swasta. Lebih dari itu, pemerintah juga sedang menyusun Rancangan UU Tabungan Perumahan Rakyat(Tapera) yang dimaksudkan untuk menghimpun dana sesuai dengan karakteristik pembangunan perumahan yang umumnya berjangka panjang. Jika UU Tapera ini pada akhirnya bisa digulirkan, tentu akan menambah kemampuan pemerintah dalam penerapan Land Banking khususnya pendanaan untuk mengakuisisi tanah-tanah objek Land Banking.

Penerapan konsep Land Bankingdi Indonesia sebetulnya sudah dilaksanakan sejak beberapa tahun lalu. Ada dua pihak yang melaksanakannya. Pertama, pihak swasta yang telah banyak mengakuisisi lahan dengan dukungan kekuatan financial yang dimilikinya. Salah satu contoh penerapannya seperti yang terjadi di Serpong, Tangerang. Pada tahun 1980, pihak swasta membeli lahan ratusan hingga ribuan hektar ketika daerah tersebut masih sepi dan minim aksesibilitasnya sehingga harga tanah masih relatif murah ketika itu. Secara bertahap pihak swasta kemudian 
membangun daerah tersebut menjadi kawasan perumahan dengan nama Bumi Serpong Damai (BSD) yang saat ini sudah berubah menjadi kota yang ramai dengan segala infrastruktur yang lengkap. Tentu Developermendapatkan perbedaan harga tanah ketika membeli dahulu dan menjualnya saat ini. Kondisi seperti itu juga banyak dilaksanakan di daerah Cibubur, Karawaci, Cikarang, Sentul dan daerah lainnya dengan melibatkan banyak pihak swasta. Pihak swasta meng-akuisisi tanah, menyimpan dan mencadangkannya untuk dibangun di kemudian hari. Kedua, adalah pihak pemerintah yang diwakili oleh Perumnas. Sebuah perusahaan BUMN yang keseluruhan sahamnya dimiliki pemerintah. Namun karena kekuatan finansialnya terbatas tentu tidak 'selincah' pihak swasta dalam menjalankan mekanisme Land Banking tersebut. Sesuai dengan tujuannya, Perumnas kemudian membangun perumahan dalam skala besar di atas lahan-lahan yang dimilikinya. Berbeda dengan pihak swasta yang bebas menentukan harga akhir produk rumahnya, Perumnas dibatasi oleh misinya untuk membangun rumahdengan harga rumah yangterjangkau oleh masyarakat terutama golongan MBR. Perumahan skala besar yang sudah dibangun di antaranya berada di Bogor, Bekasi, Karawang, Malang, Bandung, Medan, Banjarmasin dan lain-lain. Hingga pertengahan 2012, Perumnas sudah memiliki cadangan lahan sekitar 1.900 ha. Andalan utama Perumnas dalam mengakuisisi lahan adalah bekerjasama dengan BUMN/BUMD untuk memanfaatkan tanah yang belum dimanfaatkan, misalnya milik BUMN perkebunan, KAI atau milik Pemerintah Daerah.

\section{PENUTUP}

Dari uraian di atas dapat disimpulkan bahwa mahalnya harga tanah di kawasan perkotaan menjadi faktor penghambat utama bagi pihak-pihak yang berkepentingan untuk membangun perumahan MBR.Tingginya harga tanah karena keterbatasan tanah di kawasan Perkotaan sehingga terjadi ketidakseimbangan supply dan demand. Suatu mekanisme penyediaan tanah dengan konsep Land Banking bisa menjadi salah satu solusi. Pada dasarnya konsep Land Banking bukan lah konsep baru, konsep ini sudah dilaksanakan di banyak negara sejak beberapa dekade yang lalu. Konsep Land Banking adalah penyediaan tanah pada suatu area untuk kemudian disimpan dan dicadangkan guna pembangunan di masa yang akan datang. Maksud utamayang ingin diperoleh dengan mekanisma Land Banking ini pada dasarnya adalah agar pemanfaatan tanah di kawasan perkotaan menjadi optimal dan terdistribusi dengan baik untuk segala lapisan masyarakat di perkotaan khususnya pembangunan kawasan hunian bagi MBR. Penerapan konsep Land Banking sebetulnya sudah dilaksanakan di Indonesia baik dilaksanakan oleh pihak swasta maupun pemerintah. Berbeda dengan pihak swasta yang berorientasi keuntungan, bagi pihak pemerintah yang membangun pada lahan cadangan yang dimilikinya tetap membawa misi membangun perumahan bagi golongan MBR sehingga tidak sebebas pihak swasta dalam menentukan harga rumah di atas lahan-lahan tersebut.

\section{DAFTAR PUSTAKA}

Alexander, F.S. (2011). Land Banks and Land Banking. Washington: Center for Community Progress.

Annaningsih, S. W. (2007). Penerapan konsep bank tanah dalam pembangunan tanah perkotaan. Jurnal UNDIP tentang Masalah-masalah Hukum, 36(4), Semarang.

Evans, A. (2004). Economics, Real Estate and the Supply of Land. New Jersey: John Wiley \& Sons.

Sujarto, D. (2005). Masa depan kota dan reorientasi perencanaan tata ruang kota Indonesia. Bunga Rampai Pembangunan Kota Indonesia dalam Abad 21 Pengalaman Pembangunan Perkotaan di Indonesia. Jakarta: URDI \& YSS. 